\title{
Somogyvári Lajos
}

Pannon Egyetem MFTK TK

\section{Munkára nevelés a szocialista pedagógiában: az orosz-szovjet elötörténet (1917-1958)}

\begin{abstract}
A munka és a pedagógia világa egymást kölcsönösen feltételező szféra, melyek $\triangle$ különböző kapcsolatban voltak a történelem folyamán - ennek egyik jellemző forImájáról szól írásom. A politechnikai képzés a munkára nevelés fogalomkörének sajátos elméleti és gyakorlati megvalósulása, mely a marxista ideológiában gyökerezik, az 1917 utáni orosz-szovjet neveléstudomány és pedagógia fejlődéstörténetéből bontható ki. Az elsődleges szempontot mindig is az ideológiai és a népgazdasági érdek váltakozó hangsúlyai jelentették a politechnikai képzésben, időszakonként változó reformpedagógiai hivatkozásokkal és legitimációval - átalakulásokkal és gyakori váltásokkal leírható történelmi folyamat alkotja írásom fö témáját, a munkára nevelés 1917 és 1958 közötti, orosz-szovjet fejlődéstörténetét.
\end{abstract}

\section{Az ideológiai alapok - Marx és Engels}

A kiindulópontot a 19. század kapitalista viszonyainak kritikája jelentette: a gyáripar és a gépesítés megnyomorító, elidegenítő hatásáról Marx és Engels számos írása tanúskodik - a tőkés fejlődés egyik legfontosabb következménye a szellemi és fizikai munka szétválása, a túlzott szakmai specializáció, ami korlátoltságot okoz (a szövegekhez ld. Vág, 1967, 34-56., 62-67., 70-72. o.). A cél a szétforgácsolt erők egyesítése, az ember felszabadítása a magántulajdon és a kapitalista munkamegosztás eltörlésével, a termelőerök bázisán. A gép és az automatizálás, amely korábban eltávolított és elidegenített, itt már a szellemi és fizikai munka egyesítését jelenti - az ellentmondás feloldását a társadalmi viszonyok különbsége jelentheti, bár ez a probléma nincs részletesen kifejtve Marxnál vagy Engelsnél. Az antikapitalizmus határozza meg a jövő elképzelését, amelyben fontos szerep jut a kommunista emberek nevelésének. Ebben a folyamatban kell a politechnikai képzést szemlélnünk az ideológia szerint. A politechnikai képzéssel kapcsolatban legtöbbet hivatkozott marxi szöveghely 1866-ból való:

„Nevelésen három dolgot értünk.

Elöször: szellemi nevelést.

Másodszor: Testi nevelést, amelyet gimnasztikai iskolákban és katonai gyakorlatokkal nyújtanak.

Harmadszor: Technológiai képzést, amely közli valamennyi termelési folyamat általános alapelveit, és egyúttal bevezeti a gyermeket és az ifjút valamennyi szakma elemi szerszámainak gyakorlati használatába és kezelésébe." (Karl Marx: Instrukciók az ideiglenes Központi Tanács küldöttei számára, ld. Vág, 1967, 105. o.) 
A német eredeti konkrétabb a magyar fordításnál: „Geistige Bildung - Körperliche Ausbildung - Polytechnische Erziehung" (Marxot idézi: Skiera, 2009, 127. o.). Az idézetekből kibontható a későbbi szocialista pedagógia egyik alaptétele, az iskolareformok diskurzusaiban gyakran használt érv: a mindenoldalúan fejlett ember eszméje. A régi iskolával szemben az új nemcsak az intellektuális képességek fejlesztésére helyezi a hangsúlyt: ugyanolyan fontos (ha nem fontosabb) a „kéz müveltsége” (Sáska, 2005b, 18. o.) - ami egyébként a reformpedagógiai mozgalmakkal érintkező gondolat - és a fizikai képzés, a testi nevelés. „Ahogyan a természet rendszerében fej és kéz összetartoznak, úgy egyesíti a munkafolyamat fejmunkát és kézmunkát." (Marxot idézi: Márkus, 1971, 46. o.) A politechnikai képzés egyik első megfogalmazásában már jelen van a termelőmunka fontossága és valamennyi technikai alapkészség elsajátítása a növendékek által. Az idézettel kapcsolatos utolsó fontos megjegyzés a termelési folyamatok alapelveit illeti. Krupszkaja és Lenin más megközelítésben fogalmazza meg ugyanezt a tartalmat: a későbbiekben ismertetendő, az egész oktatási folyamatot átható politechnikai alapelv formájában. Marx A tőkében (A gyermekek termelömunkája és nevelése, idézi: Vág, 1967, 121-122. o.) folytatja idevágó gondolatmenetét:

„A gyárrendszerből - ahogyan Robert Owennél részleteiben nyomon követhetjük - kisarjadt a csírája a jövő nevelésének, amely minden gyermek számára egy bizonyos koron túl összekapcsolja majd a termelömunkát az oktatással és a tornával, nemcsak egyik módszerként a társadalmi termelés fokozására, hanem az egyetlen módszerként mindenoldalúan fejlett emberek termelésére."

A három terület (szellemi, testi és politechnikai nevelés) összekapcsolásából vezeti le Marx a mindenoldalúan fejlett emberek termelésének szándékát. Két fontos, új elem bukkan itt elő: az egyik a jövő nevelésére vonatkozik, a másik oktatás és termelőmunka összekapcsolására. A szocialista pedagógia fontos jellemzője volt - minden gyakorlatiassága ellenére - a jövőre irányuló, némileg utópisztikus jelleg, a képzés céljául tekintett embereszmény megfogalmazása és az elérés útjainak felvázolása. Természetesen minden pedagógia teleologikus és célvezérelt, azonban a szocialista pedagógia esetében az ideológia (a kommunista társadalom megvalósításának távlati célja) dominanciája miatt nagyobb hangsúlyt kapott az alapul tekintett ideál. Eszmény és gyakorlat egymáshoz igazítása, illetve az oktatáspolitikai döntéseket befolyásoló, azokat alátámasztó praktikus és elméleti érvek változó erőssége sok konfliktushoz vezetett az iskolareformok bevezetésének idején. A termelőmunka és az oktatás-nevelés kombinációja volt az alapja ezeknek a reformoknak, a marxi indoklással (gazdasági és társadalmi érdekek) együtt ez az okfejtés képezte az alapját Hruscsov 1958-as előterjesztésének, ami megelőzte a szovjet oktatási törvényt, az iskolareformot.

A politechnikai képzés ideológiai megalapozását követően az orosz-szovjet pedagógia fejlődéstörténetét vázolom fel 1917 után. A politechnikai képzés szempontjából három nagyobb korszakra oszthatjuk fel a hruscsovi reformokat megelöző négy évtizedet:

1. a kísérletezés időszaka (1917-1931),

2. visszatérés a hagyományos iskolamodellhez a sztálini represszió idején (1931-1953), 3. a reform előzményei, Hruscsov hatalmi harcai (1953-1958).

A periodizáció alapjául szolgáló fordulópontok a következők: a bolsevik hatalomátvétel (1917), a pedagógiai kísérletezést lezáró párthatározatok (1931), Sztálin halála (1953) és a szovjet iskolarendszer átalakításának kezdete (1958). Valamennyi évszám oktatáspolitikai és ideológiai irányváltást jelöl - a Sztálin halálát követő váltás hosszan elhúzódó jellegével eltér a többi átalakulástól, amelyek hirtelen következtek be (ennek lehetséges okairól később lesz szó). A váltások minden esetben a hatalmi-politikai erőtérből indul- 
tak ki, a felülről kikényszerített fordulatokat az oktatáspolitika többi szereplöje (pedagógusok, neveléstudomány, szülők, diákok) passzívan elszenvedte és érdekérvényesítő képességétől függően reagált rá - aktív kezdeményező szerepben csak az állampárt és az adminisztráció léphetett fel.

\section{A kísérletezés időszaka - orosz-szovjet oktatáspolitika 1917 és 1931 között}

Az ideológia gyakorlatban való kipróbálásának és továbbfejlesztésének periódusa ez, az oktatáspolitikára döntő befolyást gyakorló főbb személyek Lenin, Krupszkaja és Lunacsarszkij voltak a hosszú húszas évtizedben, s ekkor múködött Makarenko is, akinek személye átmenetet képez a harmincas évek felé (írásai az '50-es évek második felétől kezdenek el nagy hatást gyakorolni a pedagógiai diskurzusokra). A munkaiskola koncepcióját kidolgozó Blonszkijt szintén meg kell említeni ebben a felsorolásban, bár ő kilóg a sorból, hiszen a pedológia híveként hamar kiszorult a szovjet pedagógiai nyilvánosságból.

Lenin marxi alapokra helyezkedve már 1917 előtt az oktatás és a termelőmunka összekapcsolását hirdette, amit kiegészített az általános, ingyenes és kötelező oktatás pontjával és a 16 éves korig tartó tankötelezettséggel (az OSZDMP programja és annak átdolgozása - ld. Vág, 1967, 208-209., 271-272. o.). A hatalomra került bolsevikok bővítették célkitüzéseiket: az Oroszországi Kommunista (bolsevik) Párt programjában (1918) már ,ingyenes és kötelezó általános és politechnikai [...] oktatás” szerepel, ami a termelés minden ágával megismerteti a diákokat, elméletileg és gyakorlatilag egyaránt (Vág, 1967, 288-289. o.). A párt VIII. kongresszusa 1919-ben elfogadta az általános és politechnikai képzés bevezetését 17 éves tankötelezettséggel, valamint a tanítás és a társadalmilag hasznos munka (elmélet és gyakorlat) egységét. Lenin a társadalmilag hasznos munkát praktikus érdekek mentén értelmezte: a polgárháború és az intervenció éveiben a villamosítás ${ }^{1}$, az élelmiszerhiány megoldása, az új szovjet hatalom védelme, az ipar és mezőgazdaság újraindítása voltak az elsődleges szempontok, amiket a fiatalság elé állított megoldandó feladatként a bolsevik vezető (Skatkin, 1963, 35. o.). A gazdasági tervszerüséget a közoktatás területére is ki akarta terjeszteni (Krupszkaja, 1966, 182. o.) - a húszas évek további oktatáspolitikája ezt a megállapítást némileg megkérdőjelezi. Lenin (1948, 418-424. o.) ehhez hozzátette, hogy a jövő kommunista társadalmának felépítéséhez tudományos alapok kellenek (újabb képzési célterület), melyek a gazdasági hatékonyságot is növelik, az iskolát nem szabad elszakítani az élettől. Csupa olyan gondolat, mely majd a hruscsovi reformban is visszaköszön.

Habár Lenin többször is hangsúlyozta a politechnikai képzés azonnali bevezetését - „a lehetőséghez képest máris" (Vág, 1967, 312. o.) -, ez nem valósult meg. A gyakorlatban a hagyományos kézimunka (szabás, varrás, asztalosmunkák) éledt újjá politechnika címszó alatt (Skatkin, 1963, 38. o.), és nem a modern, termelö üzemekre alapított iskolaszervezés. A kényszerítő szakember-szükséglet felülírta a programokat: az 1920-as X. kongresszusra készülve Lenin módosította Krupszkaja téziseit, mivel szükségesnek tartotta a középfokú oktatás felsőbb évfolyamainak összevonását a technikai szakiskolákkal. Az eredeti célkitüzéshez képest ez kényszermegoldás volt, amit Lenin is érezhetett, hiszen javaslatát így folytatta: „1. kerüljük el a korai szakosítást [...] 2. az összes technikai szakiskolákban biztosítsunk nagyobb teret az általánosan müvelö tárgyaknak." (Vág, 1967, 312. o.). Nem véletlen a pontosítás, hiszen a mindenoldalúan fejlett szocialista ember képzésének eszménye és az eredeti politechnikai elv sérült itt meg. A praxis előtérbe helyezése (ennek jelentőségéhez bővebben ld.: Krausz, 2008, 189-191. o.) és az ideológia hozzáigazítása a taktikai-gyakorlati elvekhez minden kommunista vezetőre jellemző lesz majd Lenin után. 
Az oktatáspolitikát 1929-ig Lunacsarszkij vezette közoktatásügyi népbiztosként munkatársai között ott volt Krupszkaja is, Lenin felesége. Az új oktatási rendszer megszervezése rögtön vitákat okozott a NARKOMPROS (a Közoktatásügyi Népbiztosság orosz betüszava) szervezetén belül, amely elörevetítette a későbbi frontvonalakat is a politechnika értelmezésében. Alapvetően két fö irány alakult ki: a petrográdi csoport Lunacsarszkij és Menzsinszkaja vezetésével a gyermek személyiségének teljes fejlesztését vallotta, a Dewey-féle 'activity school' módszerét követve. A reformpedagógiai progresszív elemek (föleg a tekintélyellenesség) később az egységes munkaiskoláról szóló rendeletre is rányomták a bélyegüket. A petrográdiak politechnikai képzés alatt a technikai alapkészségekkel való megismerkedést értették, amely iskolai tanmühelyekben folyik. Ezzel szemben a moszkvai csoport (Lepesinszkij és Pozner) túl akadémikusnak tartotta ezt az elképzelést - a politechnikát szerintük nem tanmühelyekben, hanem az életben kell elsajátítani, a mezőgazdasági és ipari munkában való részvétellel. Nem az egyéniséget, hanem a közösséget tartották a nevelés-oktatás alapjának - az iskola-kommunát a diákok számára egész évre szóló környezetként definiálták (a vita összefoglalása a következő müvön alapult: Fitzpatrick, 1970). Ezek az elképzelések Makarenkónál bukkantak fel később, illetve a már említett rendelet iskolai önkormányzatról szóló részében. Az ellentétet a világhoz való aktív, kreatív odafordulás ('activity school') és az élethez szükséges gyakorlati ismeretek elképzelése (a marxi gondolat) között nem lehetett kibékíteni, így a már említett, 1918. október 16-án megjelent rendelet az egységes munkaiskoláról megpróbálta összeegyeztetni a széttartó elemeket. A húszas éveket meghatározó dokumentumot (a szöveget ld. Vág, 1977, 25-30. o.) részletesebben elemzem a továbbiakban.

$\mathrm{Az}$ általános és egységes képzés nagyon fontos koncepciót takart, ez pedig az esélyegyenlőség és a tudás demokratizmusának biztosítása, ami elvezetett az oktatás proletarizálásához, vagyis a munkás-parasztszármazású gyerekek automatikus előnyben

Az új oktatási rendszer megszervezése rögtön vitákat okozott a NARKOMPROS (a Közoktatásügyi Népbiztosság orosz betúszava) szervezetén belül, amely elórevetítette a késóbbi frontvonalakat is a politechnika értelmezésében. Alapvetöen két fö irány alakult ki: a petrográdi

csoport Lunacsarszkij és

Menzsinszkaja vezetésével a gyermek személyiségének teljes fejlesztését vallotta, a Dewey-féle 'activity school' módszerét követve. A reformpedagógiai progreszszív elemek (fóleg a tekintélyelle-

nesség) késóbb az egységes munkaiskoláról szóló rendeletre

is rányomták a bélyegüket. A petrográdiak politechnikai képzés alatt a technikai alapkészségekkel való megismerkedést értették, amely iskolai tanmühelyekben folyik. Ezzel szem-

ben a moszkvai csoport (Lepesinszkij és Pozner) túl akadémikusnak tartotta ezt az elképzelést - a politechnikát szerintük nem tanmühelyekben, hanem az életben kell elsajátita-

ni, a mezógazdasági és ipari munkában való részvétellel. részesítéséhez az iskoláztatásban. Az általános és középfokot is magában foglaló egységes munkaiskola egyik fö alapelve a tanítás módszereként felfogott, társadalmilag hasznos termelömunka lett. A 17 éves korig tartó ,általánosan képző politechnikai 
oktatás" fogalma érdekesen ötvözte magában az eltérő nézeteket. A termelési formák megismerése marxi eredetü, de a gyermek önként végzett, ,alkotó jellegü és örömteli” munkája, az állampolgári nevelés és a régi típusú fegyelmezési formák eltörlése már tipikusan reformpedagógiai megfogalmazás. A régi iskola eltörlésének szándéka odáig vitte a rendelet íróit, hogy betiltották a házi feladatot, a vizsgáztatást és bármiféle büntetést az iskolában. Ugyanakkor bekerült a jogi szövegbe a kollektív, közösségért végzett munka fontossága, továbbá az iskolai életet irányító, valamennyi tanulót és dolgozót magában foglaló Iskolatanács - ezek az elemek pedig a moszkvai csoport nézeteit tükrözték, jóllehet az önkormányzatiság számos reformpedagógiai elgondolásnak is a része. Az egységes munkaiskola első fokozata (eredetileg 8 és 13 éves kor között) a munkára nevelés előkészítését szolgálta, a második fokozatban (13 és 17 éves kor között) lett volna a termelömunkában való részvétel, fokozott hangsúllyal a kémia, technika és népgazdaság ismeretén (Krupszkaja, 1966, 11-12. o.).

A politechnika egyik korai gyakorlati megvalósítása Blonszkij nevéhez füződik, aki 1918-ban Moszkvában munkaiskolát alapított - koncepciójában (Blonszkij, 1974) a munkára nevelés kooperáción alapuló közösségi nevelést jelent. Szembefordul Kerschensteiner szakmai kézmüves iskolájával, amennyiben a tudományos technológiai fejlődés alapján álló sokoldalú képzést szorgalmazza, amely tudás a gyáriparban is kamatoztatható. Az életszükségletekből kiinduló, gépesített termelés az ideális nevelési terep, amelynek kiindulópontja a gyermeki kíváncsiság, az utánzásos játék. A reformpedagógiai (krupszkajai-lunacsarszkiji) vonalnak némiképp ellentmond az elhatárolódás az aktív szemléltetésre építő iskolától (ez Dewey iskolája), mivel Blonszkij nem ért egyet annak kulturális tartalmával. A parancsnokok által irányított csoportok képe inkább Makarenko nevelési elképzeléseire hasonlít.

Makarenko munkássága közismert a Gorkij-telep (1920-1928) és a Dzserzsinszkij-kommuna (1928-1935) irodalommá stilizált történetéből, így elsősorban a politechnikai képzés szempontjából fontos elemeket emelem ki gondolkodásából (ehhez a következő munkákat vettem alapul: Makarenko, 1964, 1965; Pataki, 1988). A munka Makarenko számára pedagógiai és közösségalkotó szerepe miatt fontos. Az iskolát olyan gazdasági egységként fogta fel, ahol a nevelés és a termelés közvetlenül összekapcsolható, az általános képzés és a termelömunka egysége lehet a mindenoldalúan fejlett emberek létrehozásának alapja. Elvetette a pszichológiai megközelítést és a pedagógiai elméletek túlburjánzását - ebben a tekintetben ellentétbe került korábbi mesterével, Krupszkajával és a húszas évek kísérletezésével -, mindig a tényekből és a nevelési-oktatási gyakorlatból indult ki a tevékenysége. A munkafolyamatok kivitelezésében nagy szerepet játszott a közösségi militarizálás esztétikuma (munkaosztagok, parancsnokok), a kölcsönös felelösség és önkormányzatiság eszméje. A társadalmi nevelés egyik szószólójaként Makarenko a családot olyan idejétmúlt intézménynek tartotta eleinte, mely el fog halni (Sulginnal és más túlzó baloldaliakkal együtt, ld. még az állam elhalásáról szóló lenini téziseket), s helyét a szocialista nevelöiskola veszi át.

Blonszkij, Makarenko és még néhány pedagógus meg tudta valósítani a munkaiskolát a gyakorlatban is, a nagy tervek és ígéretek többsége azonban papíron maradt, hiszen hiányoztak az anyagi, infrastrukturális és személyi feltételek a megvalósításhoz. Lunacsarszkij a munkaiskola alapelveinek felvázolásakor elismerte a reform részleges jellegét, az oktatási rendszer zürzavarát, miközben tovább árnyalta az új munkaiskola szemléleti és gondolkodásbeli elemeit. A munkaelv szerinte ,a világ aktív, mozgékony, alkotó megismerését" jelenti, Fröbel rendszerére alapozva, illetve a mezőgazdasági és ipari munkafolyamatok megismerését idősebb korban (Vág, 1977, 31-34. o.). A koncepció nagyon sok időt vett volna igénybe, aminek határokat szabtak a gazdasági igények és az oktatási rendszer teherbíróképessége - ezt jelzi, hogy 1921-ben a kormány leszállította a tankötelezettség korhatárát 17 évről 15 évre. Habár továbbra is hangoztatták 
az elméleti pedagógiában az általános és politechnikai képzés elvét, de ez leginkább a konferenciák állandó témája maradt, és nem vált iskolai valósággá (DeWitt, 1968). Az új iskolatípust meg kellett védeni az uniformizálás és a munkaoktatáshoz hiányzó feltételek vádjaitól - Krupszkaja írásában (ld. Vág, 1977, 92-96. o.) nemcsak ezt tette meg, hanem a készülö tantervekről is beszámolt. Az egységes iskola II. fokozatában (13 éves kortól) első évfolyamon a nyersanyag-kitermelö ipart és a földmüvelést ismerik meg a diákok, második évben pedig feldolgozóiparral foglalkoznak - a hagyományos tantárgyakat is a termelőmunka elméletéhez, gyakorlatához igazítják a tervezet szerint. „Kerülni kell az enciklopedikus tudásra törekvést" Krupszkaja szerint, ami a régi könyviskola elleni újabb reformpedagógiai támadásként értékelhető, illetve a túlterhelés hagyományos problematikáját a közismeret megnyirbálásával oldja meg (nem véletlen, hogy a pedagógusok részéröl támadások érték a koncepciót). Olyan új iskolatípusok is kialakultak ugyanebben az időszakban, melyek inkább a szükebb körü, speciális szakképzéshez álltak közel - ilyenek voltak a Komszomol üzemi szakiskolái², vagy a parasztifjúság számára megszervezett hasonló intézmények. Krupszkaja ezeket a kompromisszumos formákat is politechnikai tartalommal kívánta megtölteni, több-kevesebb sikerrel (Krupszkaja, 1966, 21., 68., 159-160. о.).

Krupszkaja $(1949,1966)$ politechnikáról vallott nézeteit saját írásai, valamint a didaktikával foglalkozó Mihail Szkatkin és szerzőtársa szócikke alapján (Cov'janov és Skat$\left.k_{i n}{ }^{3}, 1994\right)$ foglalom össze. Krupszkaja a marxi-lenini diskurzusból indult ki, a tanítás és termelőmunka összekapcsolását a tömeges gyáripar és a modern mérnöki munka tudományos bázisán képzelte el. A politechnikát nem külön tantárgyként, egy-egy speciális munkakészség kifejlesztéseként (monotechnika) kezelte, hanem olyan alapelvként, mely minden tantárgyat át kell hasson. Az általános képzés alapján való politechnikai képzés hosszabb folyamat, de szükséges Krupszkaja szerint, mivel a munkásoknak a jövőben a technológiai és tudományos kihívások keltette változásokhoz fokozottabb mértékben kell majd alkalmazkodni. A munkaoktatás élettel való szorosabb kapcsolatát szorgalmazta azzal, hogy kritizálta az intézményeken belüli tanmühelyek gyakorlatát - a fiatalokat a gyárakba és földekre kell kivinni, hogy tapasztalatot szerezzenek.

A krupszkajai és lunacsarszkiji munkára nevelés legföbb sajátossága a gyermeki egyéniségből kiinduló, mindenoldalú fejlesztés pszichológiai programja - szükségszerü volt, hogy ez a pedológiával érintkező elképzelés a harmincas évek sztálini fordulata után eltünjön a pedagógiai diskurzusból (a folyamat részletesebb leírásához ld. Sáska, 2005), helyét a makarenkói kollektív munkaiskola ideálja vette át az elméletben. Krupszkaja szerint az iskolán kívül végzett munka főbb jellemzői a helyi gazdasági tevékenységekkel való kapcsolat, harmónia, aktivitás, tudatosság és az öröm (az első kivételével mindegyik pszichológiai eredetü). A megközelítésmód folyományaként egy később nagy karriert befutó kutatási irányt jelölt ki Krupszkaja a pszichotechnika fogalmával. A pszichotechnika a 20. század elejétől létező, alkalmazott lélektan, munka- és szervezetpszichológia volt, német és amerikai tudósok (például Stern, Münsterberg, Wundt, Emerson, Parsons; ld. Fekete, 1940) fejlesztették ki az optimális munkaszervezés és az eredményes munkavégzés érdekében - ennyiben rokoníthatóak ezek a vizsgálatok a hírhedt taylori módszerekkel. A burzsoá pszichotechnikát elveti Krupszkaja mint a kizsákmányolás egy újabb eszközét, az új szovjet pszichotechnikában elsősorban olyan pályaválasztási tanácsadást lát, amelyik feltérképezi az egyéni adottságokat és az ezeknek megfelelő munkaformákat - szoros kapcsolatban a pedológiával.

A húszas évek a progresszív kísérletek korszaka az orosz-szovjet közoktatásban (Dalton-terv, Winnetka-terv, Dewey és más reformpedagógusok módszereinek átvétele $)^{4}-\mathrm{az}$ oktatásirányítás pluralizmusa Lunacsarszkijnak és Krupszkajának volt köszönhető, akik személyesen támogatták az innovációkat. 1923-ra Krupszkaja vezetésével az Állami Tudományos Tanács ${ }^{5}$ pedagógiai szekciója kidolgozta az új tantervet a munkaiskolák- 
nak: a Komplex Program felhasználta a reform- és kísérleti iskolák eddigi tapasztalatait. A tanterv funkcióit abszolutizáló szemlélet okozta, hogy a tananyag helyes elrendezésével és az időterv pontos betartásával Krupszkaja megoldhatónak vélte (vagy legalábbis ezt hirdette) a munkára nevelés egész problematikáját (Krupszkaja, 1966, 14-15. o.). Ezt követően széles körü vita bontakozott ki a progresszív irányzatokról, amiben már kritikus hangok is megszólaltak a kísérletezéssel kapcsolatban. A marxista pedagógusok többek között Dewey-t bírálták, mert kikerülte az osztályharc problematikáját, és nem akarta megváltoztatni a fennálló társadalmi viszonyokat, ezzel pedig a burzsoázia, az imperializmus érdekeit szolgálja (Mchitarjan, 2000).

A húszas éveknek az 1931-es párthatározat vetett véget. A tolsztoji „szabad nevelés” korszaka lezárult, a viták és pluralizmus helyét a hagyományos iskolamodell restaurációja vette át, annak minden következményével együtt. A politechnikai képzés és az egyéniség szempontjai háttérbe szorultak, hogy helyüket a tantárgyi-diszciplináris rendszer fegyelme és a közösség elsődlegessége vegye át. A politikai váltással együtt járt a pedagógiai hagyományok és kánon átértelmezése: Krupszkaja és Lunacsarszkij háttérbe szorult, Makarenko (időlegesen) az előtérbe került. Marx és Lenin állandó hivatkozási pontot jelentett, bár amikor Hruscsov az 1950-es évek második felében meghirdette a lenini alapelvekhez való visszatérést, akkor az már teljesen mást jelentett, mint a harmincas években a lenini életmü folytatása - legitimációs alapként - Sztálin számára.

\section{A hagyományos iskolarendszer visszaállítása Sztálin idején (1931-1953)}

Az 1931. szeptember 5-i KB-határozat radikális váltást hozott a szovjet oktatáspolitikában: a kísérletezésnek véget vetettek, a politechnizációt alárendelték az oktatási-tanítási célnak, ami egyet jelentett a munkára nevelés háttérbe szorulásával - habár jelszavak szintjén tovább élt a politechnikai oktatás, a kérdés komolyabban az ötvenes években került újra elő (DeWitt, 1968, 242-243. o.). Az 1931-es határozat szövege szerint (a forrást ld. Daniels, 1993, 187-188. o.) a korabeli szovjet iskola nem nyújtott elégséges, a technikai fejlődéshez szükséges, megalapozott diszciplináris tudást, röviden: el volt maradva a szocialista fejlödés szintjétől. A kétfrontos harc jól ismert toposza is előfordul a dokumentumban: a jobboldali elhajlás, a könyviskola visszaállítása ellen éppen úgy küzdeni kell, mint az iskola elhalásáról és a tanár szerepének redukciójáról szóló baloldali, opportunista nézetekkel. Valójában a tanári tekintélyt és a fegyelmet kell visszahelyezni a jogaiba, ezzel párhuzamosan pedig a pártszervezetek iskolák feletti felügyeletét és irányítását is erősítették az élesedő osztályharc szellemében.

A forrásból kitünik az akadémiai tudás felértékelődése, amit a felsőfokra való felkészítés szándéka indokolt, ugyanis az iparosítás egyre több képzett szakembert igényelt (Kairov, 1958). Az ideológiai elem és a pártirányítás újra hangsúlyos szerepet kapott, a tradicionális iskolarendszer restaurációja együtt járt az ötfokozatú osztályozás visszaállításával, új tankönyvek bevezetésével. A hatalmi szimbólumok szintén a régi időket idézték (ez a háború alatt egészen az ortodoxiával való kibékülésig vezetett), a forradalmi legitimációt - hatalmi érdekből - a nemzeti váltotta fel. 1936-ban újabb határozat született, ezúttal a pedológiai eltévelyedésről - a gyermektanulmányt és a pszichológiát anti-marxista pszeudo-tudományként bélyegezték meg, és kitiltották az iskolából (Zepper és Brickman, 1989, 34-35. o.). Az ugyanebben az évben kiadott szovjet alkotmány 121. cikkelye az általános és kötelező alap-, középfokú oktatás színhelyeként még megjelöli a gyárakat, állami gazdaságokat és traktorállomásokat (Constitution..., 1936, 230. o.), de ekkor már másként definiálták elmélet és gyakorlat lenini egységének elvét, mint a húszas években. ${ }^{6}$ Szkatkin, a Tanításmódszertani Intézet tagja az osztálytermi tanítást, 
a tudomány alapjainak elsajátítását tekintette elsődlegesnek, amit csak kiegészít a gyakorlati alkalmazás, ez utóbbi szempont egyedül a munka-habitus kialakításában fontos (DeWitt, 1968, 244. o.).

A párt 1939-es, XVIII. kongresszusának előterjesztése még mindig a szovjet rendszer konszolidálásáról, a kulturális forradalom eredményeiről, a felsőoktatást elvégző minél több szakértő, az új intelligencia kialakításának szándékáról szólt (Stalin, 1978, 391-393. o.). A rendszer fő feladata a munkásosztály vezető szerepének biztosítása volt, a közoktatás ennek megfelelően széles területet ölelt át (gyárak, mezőgazdasági üzemek) - a munkára nevelésnek csak a színtere maradt meg 1936 és 1939 után mint az oktatás táptalaja. 1941 után újra előkerült a munka felhasználása a pedagógiában, de ez háborús szükségszerüség, a honvédelem érdeke volt: a gyerekek segítettek a mezőgazdasági begyüjtésben, a védelmi tevékenységben, az otthon maradt családok segítésében (Goncharov és Yesipov, 1947, 14., 67-70. o.).

A háború utáni években az iskolarendszer rekonstrukciója, az új világrend kialakítása, a nemzetközi viszonyok átrendeződése kötötte le a sztálini rendszer energiáit, a munkára nevelés kérdése a XIX. kongresszuson, 1952-ben vetődött fel újra. Ez az esemény már átmenetet képez az iskolareformként definiált változásokat előkészítő időszakhoz, s ez vezetett el az 1958-as szovjet közoktatási törvényhez. Ezt követően a Szovjetunióban és a szocialista blokk többi országában a nevelés-oktatás részévé tették a termelésben való részvételt, illetve annak előkészítését, a XIX. kongresszuson azonban még csak elkezdődött ez a folyamat. A párt két fő feladatot tüzött ki a közoktatás számára az ötödik ötéves terv keretében - hivatalosan Sztálin kezdeményezésére, de a generalisszimusz ekkor már kevesebbet szerepelt a korábbi kongresszusokhoz képest, a főbb előterjesztéseket Malenkov, Szaburov és Hruscsov tette. Az egyik cél az általános középfokú (tízosztályos) oktatás megteremtése volt, a másik pedig a politechnikai oktatásra való áttérés a középiskolákban (Az SZKP XIX. kongresszusának anyaga, 1952, 236., 285-286., 375. o.). A váltás újból gyors volt, hiszen fél évvel korábban Kairov, szovjet közoktatásügyi miniszter és a Neveléstudományi Akadémia elnöke magyar pedagógusok előtt tartott előadásában még egy szót sem ejtett a politechnikáról vagy a technológiai képzésről - az erről készült cikk 1952 áprilisában jelent meg a Köznevelésben, a kongresszus pedig ez év októberében már döntött a politechnika bevezetéséről (idézi: Knausz, 1994, 88. o.).

\section{Út az iskolareformig (1953-1958)}

1952 és 1956 között a szovjet Neveléstudományi Akadémián belül számos vita zajlott a technológiai követelmények által állított kihívásokról, a termelés és oktatás összekapcsolásának módozatairól. A Sztálin halálát követő olvadási folyamatba illeszkedett a különböző szakmai csoportok megjelenése, érdekeik artikulálása, ilyen volt például az akadémiai szféra megszólalása, Kairov 1955-ös jelentése a szovjet pedagógia helyzetéről és feladatairól. A hetvenes évek elejéröl visszatekintő szemlélet (Nagy, 1971) a dogmatizmus felszámolásának tekintette Kairov megállapításait, melyek rehabilitálták a közösségi nevelés makarenkói, marxi alapokon nyugvó koncepcióját, és újraindították a lélektani kutatásokat.

Az 1956-os XX. SZKP-kongresszus nemcsak Hruscsov titkos, a sztálinizmus büneit leleplező beszéde miatt volt fontos, az oktatás világában szintén fordulatot hozott.

Hruscsov hosszas beszámolójának kultúráról szóló részében elmarasztalta a szovjet iskolákat, mert ,az oktatás bizonyos mértékben elszakadt az élettől, az iskolát végzettek nincsenek eléggé felkészülve a gyakorlati munkára". A politechnika bevezetése nagyon lassan halad előre, az Akadémia pedig „még mindig szólamokat hangoztat”, de semmit sem tesz a munkára nevelés gyakorlati megvalósításáért. A szakmának és a tudományos 
életnek szóló figyelmeztetés a tennivalókat is felsorolta: az új tantárgyak, tantervek mellett termelési szakosítás is kell. Az iskola és élet kapcsolatát szorosabbra füzve az ipari és mezőgazdasági üzemekben hozzá kell szoktatni a tanulókat a rendszeres munkához, ami előkészíti őket a középiskola elvégzése után a gyakorlati munkára. Hruscsov az általános müveltség megalapozását ezzel párhuzamosan hangsúlyozta - a felsőbb iskolába való utat is biztosítani kell a 10 osztályt elvégzett fiúk és lányok előtt ( $A z S Z K P X X$. kongresszusa, 1956, 97. o.). A pedagógiának tehát kétirányú politikai kívánságnak kellett megfelelnie: a hagyományos elméleti, tantárgyi tudás mellett a termelésbe való bevezetés is a feladata lett. A két elvárás együttes hatása aránytalan túlterhelést okozhatott, amit részben a későbbi iskolakísérletek bizonyítottak be.

A kérdés ideológiai vonzataként a munka kommunista nevelésben betöltött szerepét említették az elfogadott irányelvek ( $A z S Z K P$..., 624. o.), ezt Hruscsov javaslatára összevontak az internátusi, kollégiumi rendszer kiépítésével: a februári határozat után 1956. szeptember elsejére felállt az új rendszer. A húszas években már felbukkant gondolatot elevenítették fel: a családi hatások gyengítésével az iskolai intézményrendszer játszik majd döntő szerepet az új szovjet ember felnevelésében (Zepper és Brickman, 2013, 42. o.), ebben a folyamatban pedig a munkára nevelés hangsúlyos szerepet fog kapni.

Az 1952-es és 1956-os kongresszus tehát egyaránt reformokat várt el a szovjet iskolától, aminek a szakma igyekezett is megfelelni. Az 1956 és 1958 közötti időszak a reformok bevezetéséről, előkészítéséről szólt. A viták eredményeként indították be az iskolakísérleteket, 585 iskolában, 8-10. évfolyamon, A termelés alapjai elnevezésü, új tantárgyat kezdték el tanítani (a Tanításmódszertani Intézet dolgozta ki ehhez az új tanterveket, tanmeneteket); Ukrajnában pedig az érettségi mellett a középiskolások szakmunkás végzettséget is kaptak (Anweiler, 1960, 22. o.; Svecov és Rozenberg, 1959). Az Akadémia új programot is kidolgozott az általános és politechnikai képzés összehangolására, az 1957-58-as tanévben a minisztérium iskoláinak 25 százaléka már eszerint müködött, egy radikálisabb kísérleti formában pedig 25 iskola vett részt. Ezekben az intézményekben az iskolai hetet két részre osztották a 9-10. osztályban: a diákok három napot elmélettel foglalkoztak, három napot pedig a termelésben töltöttek. A tapasztalatok szerint ez az oktatásszervezési forma két-három évvel hosszabbította meg a tanulmányi időt (Medlin, 1958, 13. o.), ami igazolta azt a feltevést, hogy a szakma és az általános müveltség teljes és együttes elsajátítása túlfeszíti a középiskolai kereteket. Az 1957-58as tanévben összesen 550 szovjet iskolában folytattak kísérleteket (Ábent, 1959, 859. o.), s ezek alapozták meg az egész szocialista blokkon végigsöprő oktatási reformhullámot, a munkára nevelés intézményesítését. Az eredeti kezdeményezés azonban a hatvanas évek közepére mindenhol megbukott, és a politechnika egy kevésbé nagyívü, redukált formája valósult meg.

\section{Irodalomjegyzék}

Ábent Ferenc (1959): A szovjet közoktatás átszervezésének néhány tapasztalata. Pedagógiai Szemle, $859-876$

Anweiler, O. (1960): Probleme der Schulreformen in Osteuropa. International Review of Education, 6. 1. sz. 21-35. DOI: 10.1007/bf01416663

Blonszkij, P. P. (1974): A munkaiskola. In: Ferge Zsuzsa és Háber Judit (szerk.): Az iskola szociológiai problémái. Közgazdasági és Jogi Könyvkiadó, Budapest. 481-501.
Constitution (Fundamental Law) of the Union of Soviet Socialist Republics. (1936) Kremlin, Moscow.

Cov'janov, G. S. és Skatkin, M. S. (1994): Nadezhda Krupskaya. Prospects: The Quarterly Review of Comparative Education, 24. 1-2. sz. 49-60. DOI: 10.1007/bf02199006

Daniels, R. V. (1993, szerk.): A Documentary History of Communism in Russia: From Lenin to Gorbachev. University Press of New England, Lebanon. 
DeWitt, N. (1968): The October Revolution and Soviet Education. Canadian Slavonic Papers, 10. 3. Sz. 235-253. DOI: 10.1080/00085006.1968.11091116

Faludi Szilárd, Jausz Béla és Zibolen Endre (1965, szerk.): A munkára nevelés hazai történetéböl. Akadémiai Kiadó, Budapest.

Fekete Ferenc (1940): Az ember és a munka. Korunk, 7-8. sz. 596-604.

Fitzpatrick, Sh. (1970): The Commissariat of Enlightenment: Soivet Organization of Education and the Art under Lunacharsky. Cambridge University Press, Cambridge.

Goncharov, N. K. és Yesipov, B. P. (1947): , I want to be like Stalin”. From the russian Text on Pedagogy. The John Day Company, New York.

The Great Soviet Encyclopedia. 3rd Edition. (1970-1979). 2015. 01. 02-i megtekintés, http:// encyclopedia2.thefreedictionary.com/Skatkin $\% 2 \mathrm{c}+$ Mikhail+Nikolaevich

Kairov, I. A. (1959): Basic Questions Relating to School Reorganization. Soviet Education, 1. 2. sz. 5-12.

Knausz Imre (1994): A közoktatás Magyarországon, 1945-1956. Kandidátusi disszertáció. 2015. 04. 12-i megtekintés, http://mek.oszk.hu/10000/10080/

Koginov, G. (1951): A GOELRO-terv statisztikája. Statisztikai Szemle, május, 395-408.

Krausz Tamás (2008): Lenin. Társadalomelméleti rekonstrukció. Napvilág, Budapest.

Krupszkaja, N. K. (1949): Válogatott pedagógiai tanulmányai. Hungária Könyvkiadó, Budapest.

Krupszkaja, N. K. (1966): A munkára nevelésröl és a politechnikai képzésröl. Tankönyvkiadó, Budapest.

Lenin (1948): Marx, Engels, marxizmus. Szikra, Budapest.

Makarenko, A. S. (1964): His Life and Work. Articles, Talks and reminiscences. Foreign Languages Publishing House, Moscow.

Makarenko, A. S. (1965): Problems of Soviet School Education. Progress Publishers, Moscow.

Márkus György (1971): Marxizmus és ,antropológia”. Akadémiai Kiadó, Budapest.

Mchitarjan, I. (2000): John Dewey and the Development of Education in Russia before 1930 - Report on a Forgotten Reception. Oelkers, J. és Rhyn, H. (szerk.): Dewey and European Education: General Problems and Case Studies. Springer Science - Business Media Dordrecht, Dordrecht. 109-133.

Medlin, W. K. (1958): Soviet Pedagogical Academy and the New School Plans. Comparative Education Review, 2. 2. sz. 12-14. DOI: $10.1086 / 444774$

Nagy Károly (1971): A neveléselmélet néhány időszerü kérdése. Korunk, 296-304.

Pataki Ferenc (1988): Makarenko élete és pedagógiája. Tankönyvkiadó, Budapest.

Sáska Géza (2005a): A társadalmi egyenlőség antikapitalista és demokrácia-ellenes képzete a XX. századi pedagógiai ideológiákban. 2. rész. Magyar Pedagógia, 105. 1. sz. 83-99.

Sáska Géza (2005b): A szocialista és a polgári nevelés radikális alternatívái. A gyermekközpontú ideológiák társadalomképe. Felsőoktatási Kutatóintézet, Budapest.

Skatkin, M. N. (1963): Marxist-Leninist Ideas on Polytechnical Education. In: Shapovalenko, S. G. (szerk.): Polytechnical Education in the USSR. UNESCO, Paris. 17-40.

Skiera, E. (2009): Reformpädagogik in Geschichte und Gegenwart: eine Kritische Einführung. Oldenbourg Verlag, München.

Stalin, J. V. (1978): J. V. Stalin Works. Vol. 14. 1934-1940. Red Star Press, London.

Svecov, K. és Rozenberg, M. (1959): Az oktatás és termelőmunka egyesítésének tapasztalatai az Ukrán Szovjet Szocialista Köztársaságban. Pedagógiai Szemle, 11. sz. 1020-1032.

Az SZKP XIX. kongresszusának anyaga. (1952) Szikra, Budapest.

Az SZKP XX. kongresszusa. (1956) Szikra, Budapest.

Vág Ottó (1967, szerk.): A marxista pedagógia története dokumentumokban. I. kötet. Tankönyvkiadó, Budapest.

Vág Ottó (1977, szerk.): A marxista pedagógia története dokumentumokban. III. kötet. Tankönyvkiadó, Budapest.

Waskowycz, H. (1976): Georg Kerschensteiner und das Ukrainische Schulwesen. Ukrainische Freie Universität, München.

Zepper, J. T. és Brickman, W. W. (2013): Russian and Soviet Education 1731-1989. A Multilingual Annotated Bibliography. Routledge, New York - Abingdon. 


\section{Jegyzetek}

$1 \mathrm{Ez}$ a cél a Krizsanovszkij által kidolgozott GOELRO-tervben fogalmazódott meg, ami egyben az egész népgazdaság helyreállítását is célul tüzte ki (ld. Koginov, 1951).

2 Az üzemi szakiskolákat (FZU) 1920 után a Komszomol kezdeményezésére alapították, alsófokú szakképzés céljából. 3-4 év alatt általános, politechnikai és szakmai képzést nyújtottak, 1930 után a tanulmányi időt másfél-két évre csökkentették (általában az általánosan képző hét osztály után jöttek egyébként ide a tanulók), 1939-ben pedig átszervezték (Krupszkaja, 1966, 210. o.).

3 Szkatkin a húszas években az első közoktatásügyi kísérleti állomáson dolgozott - Sackijjal együtt -, itt fejezte be pedagógiai tanulmányait 1925-ben. A harmincas években tudományos kutató volt a moszkvai Tanítóképző Intézetben, 1945-től a Pedagógiai Akadémia keretében folytatta módszertani-didaktikai vizsgálatait, melyek a politechnikai oktatást is érintették. Több természettudományi tankönyv szerzője. (Az információk az 1970 és 1979 között összeállított Nagy Szovjet Enciklopédiából valók, a másik szerzőröl nem találtam adatokat. Szkatkinhoz ld.: Skatkin, Mikhail Nikolaevich szócikk. In: The Great Soviet Encyclopedia, 3rd Edition (1970-1979).
$4 \mathrm{Az}$ orosz közoktatásnak voltak reformpedagógiai elözményei 1917 előttről is: ld. például a lenini kritikát Juzsakov 1897-es reformjavaslatairól (közli: Vág, 1967, 187-205. o.), vagy Kerschensteiner munkaiskola-koncepciójának hatását Ukrajnában (Waskowycz, 1976).

5 A Tanács 1919 és 1932 között, a Népbiztosság elméleti és módszertani központjaként müködött, pedagógiai, müvészeti és technikai szekcióval. Fö feladata a közoktatás elvi kérdéseinek és a tanterveknek a kidolgozása volt. Lunacsarszkij helyettese, a történész Pokrovszkij vezette a testületet, tagjai között ott volt Krupszkaja, Blonszkij, Sackij és Menzsinszkaja is. 1932 után a Népbiztosság Oktatásmódszertani Osztálya vette át feladatkörét (az információkhoz ld. Krupszkaja, 1966, 14., 157., 184., 210., 215. o.).

6 Ugyanakkor a szellemi és fizikai munka egyesítésének marxi gondolata újból elöbukkant Sztálin egy 1935-ös beszédében, bár ezek a kijelentések leginkább az ideológiai dekórum részét képezték (a beszédet 1d. Stalin, 1978, 89-111. o.). 